\title{
The Altman ' $Z$ ' is "50" and Still Young: Bankruptcy Prediction and Stock Market Reaction due to Sudden Exogenous Shock
}

\author{
Rajeeb Poudel \\ Western Oregon University \\ Dev Prasad \\ University of Massachusetts Lowell \\ Ravi Jain \\ University of Massachusetts Lowell
}

This study is motivated by the continuing popularity of the Altman Z-score as a measure of distress risk. This study provides a hitherto unexplored perspective by examining the relation between stock market returns and the probability of bankruptcy during an unexpected sudden shock. Following the 9/11 attacks of 2001, the US stock market dropped dramatically. We find evidence that firms which had higher bankruptcy risk experienced greater negative returns following the attack. This study suggests that the Altman Z-score is useful in identifying firms with a higher distress risk and consequent larger negative stock returns in the event of an exogenous sudden shock.

Keywords: Altman Z-score, bankruptcy probability, distress risk, stock market returns, sudden shock, financial crisis.

\section{INTRODUCTION}

This study is motivated by the fact that the Altman ' $Z$ ' measure of distress risk has turned " 50 " this year having first been introduced in 1968 by Edward Altman as a means to predicting corporate bankruptcy. In 1968, Altman suggested that corporate bankruptcy could be predicted, prior to an actual bankruptcy, through a Z-score derived using a weighted average of 5 accounting ratios. The ratios identified in the Altman study were Working capital/ Total assets, Retained Earnings/ Total assets, Earnings before interest and taxes/ Total Assets, Market value equity/ Book value of total debt, and, Sales/ Total assets. While the initial sample consisted of only 2 groups of 33 manufacturing firms, the predictive ability of the ' $Z$ ' using data from one financial statement before bankruptcy was extremely accurate since $95 \%$ of the sample was classified correctly. A reduction in the predictive ability was observed as one moved away in time from the actual event date beyond 2 years. In addition to its

applicability to bankruptcy prediction for manufacturing firms, Altman suggested that the measure could be applied in business loan evaluations, for internal control etc. 
Since 1968, during the last 50 years, the original ' $Z$ ' has faced its share of trials and tribulations as well as its successes and triumphs. Academicians from around the world have compared it with other predictive models, tested its applicability in other countries, applied to various financial crises and so on (Altman (2005), Campbell, Hilscher and Szilagyi (2008), Dichev (1998), Griffin and Lemmon (2002) and Mansi, Maxwell and Zhang (2010), Pomerleano (1999). At the end of the day, the Altman ' $Z$ ' has survived as a measure for bankruptcy prediction. Not only that, it seems to be the most popular and widely used measure in the area of financial distress and bankruptcy prediction.

Altman (2018) summarizes and expands his original list of suggested applications substantially. Altman suggests that in addition to its use by lenders for loan pricing, it can be used by bond and common stock investors, investment bankers, security analysts, regulators and government agencies, auditors, bankruptcy lawyers, bond raters, risk managers and so on. Further, Altman suggests that the ' $Z$ ' can be applied not only by those external to the firm but also by those within the firm such as board members and managers.

As mentioned earlier, some academicians have used one financial crisis or the other such as the 'Asian Crisis,' the 'Russian Crisis,' 9/11 terrorist attacks, etc. as a setting for their studies. For instance, Howe and Jain (2010) found that firms with higher level of debt suffered more negative returns during the days following the 9/11 attacks. Similarly, Jain and Prasad (2011) found that firms with higher amount of cash suffered lower negative stock returns in comparison to the firms with higher amount of cash following the 9/11 crisis. Jain, Prasad and Poudel (2019) examines the impact of 9/11 attacks on the stock prices of banking firms and finds that larger banks suffered less negative stock market reaction compared to smaller banks in the three days immediately following the attacks. However, it appears that no study has looked at the relations between distress risk, stock market and an exogenous sudden shock which created a financial crisis. Such a sudden shock occurred on September 11, 2001 a black day in American history. Using airplanes terrorists attacked the World Trade Center in New York, a major hub of financial activity, and created a sense of horror, uncertainty and panic. Following the attacks, there was a dramatic drop in the US stock market. This led to a severe financial crisis immediately but its ripple effects that has lasted till even today. The immediate effect of the sudden shock and the consequent sharp drop in the stock market was the resultant immediate negative returns as per studies such as that of Carter and Simkins (2004) which mostly focuses on the airlines industry; that of Nikkinen et al (2008) which examines the relationship between stock market sentiment and terror attacks; and, that of Nikkinen and Vähämaa (2010) which examines stock returns and volatility in 53 countries around the world following the $9 / 11$ attacks.

This study adds to the existent literature by examining a hitherto explored area as outlined further. Despite the pouring of billions of dollars by governments around the world to prevent another " $9 / 11$ " from occurring, various incidents involving several countries individually (including the USA, UK, Germany, Belgium, France etc.), incidents of terrorist attacks continue and the risks associated therewith have not been eliminated. Thus, the risk of similar exogenous shocks continues to exist. Accordingly, we wish to contribute to literature by increasing our understanding of the relationship between effects of these shocks on stock returns and its relationship with bankruptcy risk. This study investigates whether the impact of an exogenous sudden shock to the financial markets on the stock returns of firms is conditional on the firms' probability of bankruptcy. Thus, the focus of this study is to examine the relationship between the distress risk of manufacturing firms and their stock price performance in response to an exogenous sudden shock and the resultant financial crisis. Using Altman's Z, we find evidence that firms which had higher bankruptcy risk experienced greater negative returns following the attack. This study that suggests an additional way in which the Altman Z-score is a useful tool by identifying firms with a higher risk of financial failure in the event of an exogenous extreme sudden shock.

The rest of paper is organized as follows: section 2 presents development of the hypothesis; section 3 describes the data and methodology; section 4 provides a robustness check, and finally in section 5 presents a discussion of results and the conclusions. 


\section{HYPOTHESES}

Our study investigates whether the impact of an exogenous shock to the financial markets on the stock returns of firms is conditional on the firms' probability of bankruptcy as indicated by the Altman Z. We predict that firms with higher probability of bankruptcy experience more negative impact on stock returns following the attacks of September 11, 2001, a negative exogenous shock to the financial market. By the same token, we predict that firms with lower probability of bankruptcy experience less negative stock returns following the attacks. Accordingly, our hypothesis is:

$\boldsymbol{H}_{0}$ : The stock market reaction to the September 11, 2001 terrorist attacks are more negative for firms with higher probability of bankruptcy.

Acceptance of the hypothesis implies that the firms with higher probability of bankruptcy suffer more than the firms with lower probability of bankruptcy during a negative exogenous shock. We measure probability of bankruptcy with Altman's (1968) Z-Score with focus on manufacturing firms. Lower ZScore value implies higher probability of bankruptcy. Hence, we expect the firms with lower Z-Score to suffer more negative stock returns following the crisis.

\section{DATA, METHODOLOGY AND RESULTS}

\section{Data}

We obtain financial data from Compustat Annual industrial database and securities returns from Center of Research in Security Prices (CRSP) database. Only the manufacturing firms, with Compustat SIC code between 2000 and 3999, and with data on both CRSP and Compustat database are included. The financial information was taken from the calendar year 2000. We exclude firms with asset size of less than $\$ 10$ million. We also require that all the variables be available for a firm to be included in the analysis. The values for all the variables below $1 \%$ and above $99 \%$ levels are replaced with the values at those levels.

Table 1 reports the summary statistics for the characteristics of the firms used in the study. Column 1 shows the number of firms, Column 2, 3, 4, and 5 show the mean, $25^{\text {th }}$ percentile, median and $75^{\text {th }}$ percentile value. Focusing on the averages, Column 2 shows that mean (median) value of the book value of total assets is $\$ 1,165.80$ ( $\$ 155.82$ ) million. Similarly, the mean (median) market value of the firm is $\$ 2,876.23$ (\$268.27). The mean (median) market to book ratio is 3.95 (1.85). The mean (median) Z-Score is 8.39 (3.63). The mean (median) 3 -day CAR is $-2.02 \%(-2.23 \%)$.

\section{TABLE 1 \\ DESCRIPTIVE STATISTICS}

This table reports summary statistics for variables used in our regression model. 1,636 manufacturing firms are included in the sample. Market/Book ratio is market value of equity (compustat \# $199 *$ compustat \# 25) divided by the book value of equity (compustat \# 60). Tier1 is the Risk-adjusted Capital Ratio - Tier 1 (compustat \# 337) and TierT is the Risk-Adjusted Capital Ratio - Total (compustat \# 348). The 3-day CAR is the Cumulative Abnormal Return over three days following the 9/11 attacks of 2001. We compute CAR using the following regression equation:

$R_{i t}=\alpha_{p}+\beta_{p} R_{m t}+\gamma_{p k} D_{k t}+\varepsilon_{p t}$

where $\mathrm{R}_{\mathrm{it}}$ is the daily return from January 2, 2001 to Dec 31, 2001 for an individual bank. $\mathrm{R}_{\mathrm{mt}}$ is the return on CRSP value-weighted index, and $\mathrm{D}_{\mathrm{kt}}$ is equal to $1 / 3$ for each of the three event days and zero otherwise. Thus, $\gamma_{\mathrm{p}}$ represents the CAR over the three event days. 


\begin{tabular}{lccccc}
\hline Variable & $\mathrm{N}$ & Mean & $25^{\text {th }}$ & Median & $75^{\text {th }}$ percentile \\
\hline Asset- Book Value (\$ million) & 1,636 & $1,165.80$ & 45.31 & 155.82 & 630.24 \\
Asset- Market Value (\$ million) & 1,636 & $2,876.23$ & 63.02 & 268.27 & $1,169.22$ \\
Market/Book ratio & 1,636 & 3.95 & 0.95 & 1.85 & 3.87 \\
Z-Score & 1,636 & 8.39 & 2.25 & 3.63 & 6.88 \\
3-day CAR (\%) & 1,636 & -2.02 & -8.08 & -2.23 & 2.26 \\
\hline
\end{tabular}

\section{Methodology}

In our research design, the event date for all of the sample firms is the same. Thus, using the traditional market model without any adjustment will lead to the issue of heteroscedasticity and autocorrelation. In order to address these issues, we use the multivariate regression approach pioneered by Schipper and Thompson's (1983), and used by several studies like Johnson, Kasznik, and Nelson (2000) and Howe and Jain (2010). As such, we form a portfolio of subsample of firms. Then we employ the following regression model to compute the abnormal returns.

$R_{p t}=\alpha_{p}+\beta_{p} R_{m t}+\gamma_{p k} D_{k t}+\varepsilon_{p t}$

where, $\mathrm{R}_{\mathrm{pt}}$ is the daily returns on the portfolio of US manufacturing firms over the period from $01 / 02 / 2001$ to $12 / 31 / 2001$. $R_{m t}$ is the daily return on the value-weighted market returns provided by CRSP. $D_{\mathrm{kt}}$ is the dummy that equals $1 / 3$ for each of the three event days and zero otherwise. Accordingly, $\gamma_{\mathrm{p}}$ is the cumulative abnormal returns (CAR) over the event window.

Similarly, we compute Z score using the following specification as per Altman (1968).

Z Score $=1.2 *$ wcap $+1.4 *$ retain $+3.3 *$ ebit $+0.6 *$ mkval/la $+0.999 *$ sale

where, wcap is working capital calculated as current assets minus current liability, retain is retained earnings, ebit is earnings before interest and tax, mkval is market value of equity divided by total liability and sale is sales. All variables except for mkval are scaled by the book value of total assets. Following Altman (1968), we classify firms having a Z score below 1.81 as "distressed" firms, firms having a Z score between 1.81 and 2.99 as "gray area" firms, and firms having a Z score above 2.99 as "safe" firms.

In Table 2 we report the regression results for the portfolios that are equally weighted. Column 1 reports the estimates for the full sample, while Column 2, 3, and 4 report the estimates for distressed, gray, and safe firms. The significance of the coefficients is assessed using heteroscedasticity and autocorrelation consistent standard errors (Newey-West, 1987). The negative 3-day CAR of $-2.4 \%$ for the full sample is consistent with the number from the summary statistics. While the CAR for distressed firms is $-4.6 \%$, the CAR for gray firms is $-2.4 \%$, and the CAR for safe firms is $-1.8 \%$. All of the values are significant at $1 \%$ level. This result indicates that the equity market penalized the distressed firms much more heavily than either gray or safe firms during the event. 
TABLE 2

FIRM SIZE AND ABNORMAL RETURNS: EQUALLY WEIGHTED PORTFOLIOS

This table reports the Cumulative Abnormal Return (CAR) over three days following the 9/11 attacks of 2001. The CARs are computed using the following regression:

$R_{p t}=\alpha_{p}+\beta_{p} R_{m t}+\gamma_{p k} D_{k t}+\varepsilon_{p t}$

where $R_{p t}$ is the daily return over 248 days, from January 2, 2001 to Dec 31, 2001, for a portfolio of US manufacturing firms. The first column presents analysis of a portfolio of 1,636 sample firms, the second column portfolio has sample firms with Z-Score $<=1.8$ (distressed firms), the third column portfolio has sample firms with 1.8 $<$ Z-Score $<=3$ (gray firms), and the fourth column portfolio has sample firms with ZScore $>3$ (safe firms). $R_{m t}$ is the return on CRSP value-weighted index, and $D_{k t}$ is equal to $1 / 3$ for each of the three event days and zero otherwise. Thus, $\gamma \mathrm{p}$ represents the CAR over the three event days. Portfolios are created using equal weights. P-values reported in the parenthesis are based on NeweyWest (1987) heteroscedasticity and autocorrelation consistent standard errors. *,** and *** denote statistical significance at $10 \%, 5 \%$ and $1 \%$.

\begin{tabular}{lcccc}
\hline VARIABLE & $\begin{array}{c}\text { Full } \\
\text { Sample }\end{array}$ & $\begin{array}{c}\text { 3-day CAR (\%) } \\
\text { Distressed firms }\end{array}$ & $\begin{array}{c}\text { 3-day CAR (\%) } \\
\text { Gray firms }\end{array}$ & $\begin{array}{c}\text { 3-day CAR (\%) } \\
\text { Safe firms }\end{array}$ \\
\hline No. of firms & 1,636 & 284 & 348 & 1,004 \\
& & & & \\
CRSP Value-Weighted Index & $0.847^{* * *}$ & $0.717^{* * *}$ & $0.545^{* * *}$ & $0.987^{* * *}$ \\
& $(0.000)$ & $(0.000)$ & $(0.000)$ & $(0.000)$ \\
Event & $-0.024^{* * *}$ & $-0.046^{* * *}$ & $-0.024^{* * *}$ & $-0.018^{* * *}$ \\
& $(0.000)$ & $(0.000)$ & $(0.000)$ & $(0.000)$ \\
F-statistic & $594.62^{* * *}$ & $292.51^{* * *}$ & $197.03^{* * *}$ & $717.37^{* * *}$ \\
& $(0.000)$ & $(0.000)$ & $(0.000)$ & $(0.000)$ \\
\hline
\end{tabular}

In order to investigate if our results are affected by the heteroscedasticity present in our data, we use the approach pioneered by Thompson (1985). In the first step we use equation 1 above to run the regression for each firm, and then save the residuals thus obtained. In the second step, we use inverse of the variance of the residuals as the weights to form the portfolios of interest. This process of forming the portfolios asymptotically controls for arising in cross-sectional data. Table 3 displays the results. The results are consistent to those from the equally weighted portfolio. More specifically, the 3-day CAR for distressed firms $(-6.1 \%)$ is more than the CAR for either gray firms $(-4.2 \%)$ or safe firms $(-3.7 \%)$. The results are significant at $1 \%$ level. 
TABLE 3

FIRM SIZE AND ABNORMAL RETURNS: VARIANCE WEIGHTED PORTFOLIOS

This table reports the Cumulative Abnormal Return (CAR) over three days following the 9/11 attacks of 2001. The CARs are computed using the following regression

$R_{p t}=\alpha_{p}+\beta_{p} R_{m t}+\gamma_{p k} D_{k t}+\varepsilon_{p t}$

where $\mathrm{R}_{\mathrm{pt}}$ is the daily return over 248 days, from January 2, 2001 to Dec 31, 2001, for a portfolio of US manufacturing firms. The first column presents analysis of a portfolio of 1636 sample firms, the second column portfolio has sample firms with $\mathrm{Z}-\mathrm{Score}<=1.8$ (distressed firms), the third column portfolio has sample firms with $1.8<$ Z-Score $<3$ (gray firms), and the fourth column portfolio has sample firms with ZScore $>=3$ (safe firms). $R_{m t}$ is the return on CRSP value-weighted index, and $D_{k t}$ is equal to $1 / 3$ for each of the three event days and zero otherwise. Thus, $\gamma p$ represents the CAR over the three event days. Portfolios are created using equal weights. P-values reported in the parenthesis are based on NeweyWest (1987) heteroscedasticity and autocorrelation consistent standard errors. **,* and *** denote statistical significance at $10 \%, 5 \%$ and $1 \%$.

\begin{tabular}{lcccc}
\hline VARIABLE & $\begin{array}{c}\text { Full } \\
\text { Sample }\end{array}$ & $\begin{array}{c}\text { 3-day CAR } \\
(\%)\end{array}$ & $\begin{array}{c}\text { 3-day CAR } \\
(\%)\end{array}$ & $\begin{array}{c}\text { 3-day CAR } \\
(\%)\end{array}$ \\
\hline No. of firms & 1,636 & 284 & 348 & 1004 \\
& & & & \\
CRSP Value-Weighted Index & $0.534^{* * *}$ & $0.704^{* * *}$ & $0.491^{* * *}$ & $0.540^{* * *}$ \\
& $(0.000)$ & $(0.000)$ & $(0.000)$ & $(0.000)$ \\
Event & $-0.040^{* * *}$ & $-0.061^{* * *}$ & $-0.042^{* * *}$ & $-0.037 * * *$ \\
& $(0.000)$ & $(0.000)$ & $(0.000)$ & $(0.000)$ \\
F-statistic & $2813.58^{* * * *}$ & $675.98^{* * *}$ & $862.81 * * *$ & $3,243.37 * * *$ \\
& $(0.000)$ & $(0.000)$ & $(0.000)$ & $(0.000)$ \\
\hline
\end{tabular}

\section{ROBUSTNESS TEST}

Finally, to investigate whether our results presented in univariate analysis are robust to controlling for firm characteristics that are known to affect the equity return, we estimate OLS regressions in which we control for such characteristics.

Table 4 presents the regression results after controlling for Book to Market and firm size, proxied by either the book value of total assets or the market value of assets, calculated as the sum market value of equity and the book value of total liabilities. The main explanatory variable of interest is Z-Score. The dependent variable in the analysis is the CARs of the portfolios over the three-day event window calculated for an individual firm using the following model:

$R_{i t}=\alpha_{i}+\beta_{i} R_{m t}+\gamma_{i k} D_{k t}+\varepsilon_{i t}$

where, $R_{i t}$ is the daily returns on an individual US manufacturing firm over the period from 01/02/2001 to $12 / 31 / 2001$. $R_{\mathrm{mt}}$ is the daily return on the value-weighted market returns provided by CRSP. $\mathrm{D}_{\mathrm{kt}}$ is the dummy that equals $1 / 3$ for each of the three event days and zero otherwise. Accordingly, $\gamma_{p}$ is the cumulative abnormal returns (CAR) for an individual firm over the event window. 


\section{TABLE 4 \\ MULTIVARIATE ANALYSIS}

This table reports results of multivariate analysis using the Cumulative Abnormal Return over three days following the $9 / 11$ attacks of 2001 as the dependent variable. The explanatory variable of interest is the Z-Score represented by two dummies. The variable 'Gray' equals 1 if a firm is in gray area, i.e., neither safe nor distressed, 0 otherwise, and the variable "Distressed" equals 1 if a firm is in distress, 0 otherwise (safe firms being the base model. In model 1 we have two explanatory variables, the market/book ratio and the log of book value of assets. In model 2 we have market/book ratio and the log of market value of assets, which is the sum of market value of equity and the book value of liabilities. We use the following regression equation to compute 3-day CARs for each firm:

$R_{i t}=\alpha_{i}+\beta_{i} R_{m t}+\gamma_{i k} D_{k t}+\varepsilon_{i t}$

where $R_{i t}$ is the daily return from January 2, 2001 to Dec 31, 2001 on an individual US bank. $R_{m t}$ is the return on CRSP value-weighted index, and $D_{k t}$ is equal to $1 / 3$ for each of the three event days and zero otherwise. Thus, $\gamma_{\mathrm{i}}$ represents the CAR over the three event days for an individual firm. P-values reported in the parenthesis are based on robust standard errors. *,** and *** denote statistical significance at $10 \%, 5 \%$ and $1 \%$.

\begin{tabular}{lcc}
\hline Variables & $\begin{array}{c}\text { Dependent variable }= \\
\text { Model I }\end{array}$ & Modee-day CAR (\%) \\
\hline $\mathrm{N}$ & 1,636 & 1,636 \\
Market/Book ratio & .027 & .036 \\
& $(0.360)$ & $(0.240)$ \\
Log of Book Value of Assets & $-0.388^{* *}$ & \\
& $(0.028)$ & $-0.284^{*}$ \\
Log of Market Value of Assets & & $(0.086)$ \\
& & $0.064 * * *$ \\
Z-Score & $0.058^{* * *}$ & $(0.002)$ \\
& $(0.005)$ & -1.071 \\
Intercept & -0.597 & $(0.348)$ \\
& $(0.602)$ & 0.0087 \\
R-squared & 0.0097 & $5.18^{* * *}$ \\
F-statistics & $5.95^{* * *}$ & $(0.002)$ \\
& $(0.000)$ & \\
\hline
\end{tabular}

We present the results of this analysis in Table 4. Model I reports the estimates when firm size is proxied by the log of the book value of assets, and Model II reports the estimates when firm size is proxied by the log of the market value of assets. The statistical significance of the regression coefficient is assessed using robust standard errors. The positive and significant coefficients on Z-Score for both models indicate that higher Z-Score firms have more positive 3-day CARs. This finding is consistent to the findings from the analysis above. 


\section{CONCLUSIONS AND DISCUSSION OF RESULTS}

The probability of bankruptcy of a firm has a huge implication on an investor's portfolio. Investors require higher risk premium for the firms with higher probability of bankruptcy (Campbell, et.al., 2008). From a firm's perspective, this increase in risk premium implies an increase in the cost of capital. This increase in risk premia could adversely affect a firm's ability to finance capital in time of crises. As such, firms with higher distress risk can be expected to be penalized more by investors during a time of crisis. Our study examines stock returns performances of firms during September 11, 2001 crisis conditional on their probability of distress.

The results from our study indicate that firms that had higher probability of bankruptcy were more negatively impacted by the September 11 crisis than the firms with a lower probability of bankruptcy. When we examined the stock market performances of the firms after the crisis, we found that firms that were deemed "safe" based on Z-Score performed significantly better than the firms that were deemed "distressed". Our results were consistent when we examined the CARs using standard market model and then performed multivariate analysis of CARs.

The main contribution of our study is that we present evidence that the probability of bankruptcy has an implication on stock returns performance of a firm during a crisis. This evidence is of value to an investor while forming a portfolio and as well as to a firm in planning its finances and managing its risks in case of a crisis.

In conclusion, this study suggests the Altman Z-score is likely to be very useful, specially to investors and creditors as well as to board members and managers, in identifying if a firm with a higher risk is likely to experience a resultant sharper and stronger negative stock returns in the event of an exogenous sudden shock.

\section{REFERENCES}

Altman, E. I. (1968). Financial ratios, discriminant analysis and the prediction of corporate bankruptcy. The Journal of Finance, 23(4), 589-609.

Altman, E. I. (2000). Predicting financial distress of companies: revisiting the Z-score and ZETA models. Stern School of Business, New York University, 9-12.

Altman, E. I. (2005). An emerging market credit scoring system for corporate bonds. Emerging markets review, 6(4), 311-323.

Altman, E. I. (2018). Applications of Distress Prediction Models: What Have We Learned After 50 Years from the Z-Score Models. International Journal of Financial Studies, 6(70), 1-15.

Altman, E. I., Iwanicz-Drozdowska, M., Laitinen, E., \& Suvas, A. (2014). Distressed firm and bankruptcy prediction in an international context: A review and empirical analysis of Altman's Z-score model. SSRN: https://ssrn.com/abstract=2536340.

Altman, E. I., \& Saunders, A. (1997). Credit risk measurement: Developments over the last 20 years. Journal of Banking \& Finance, 21(11-12), 1721-1742.

Campbell, J. Y., Hilscher, J., \& Szilagyi, J. (2008). In search of distress risk. The Journal of Finance, 63(6), 2899-2939.

Carter, D. A., \& Simkins, B. J. (2004). The market's reaction to unexpected, catastrophic events: the case of airline stock returns and the September 11th attacks. The Quarterly Review of Economics and Finance, 44(4), 539-558.

Dichev, I. D. (1998). Is the risk of bankruptcy a systematic risk? The Journal of Finance, 53(3), 11311147.

Eisdorfer, A. (2008). Empirical evidence of risk shifting in financially distressed firms. The Journal of Finance, 63(2), 609-637.

Griffin, J. M., \& Lemmon, M. L. (2002). Book-to-market equity, distress risk, and stock returns. The Journal of Finance, 57(5), 2317-2336. 
Jain, R., \& Prasad, D. (2011). Cash - A Corporate Umbrella. The Global Journal of Finance and Economics, 7(2), 85-95

Jain, R., Prasad, D., \& Poudel, R. (2019). Big is Not Bad. Journal of Business, Economics and Technology, 22(1), 130-139

Howe, J. S., \& Jain, R. (2010). Testing the trade-off theory of capital structure. Review of Business, 31(1), 54.

Kabir, M. H., \& Hassan, M. K. (2005). The near-collapse of LTCM, US financial stock returns, and the fed. Journal of Banking and Finance, 29(2), 441-460.

Mansi, S., Maxwell, W. F., \& Zhang, A. J. (2010). Bankruptcy prediction models and the cost of debt. The Journal of Fixed Income, Mar 2012, 21(4) 25-42.

Mubashir, A., \& Bin Tariq, D. (2017). Application of financial ratios as a firm's key performance and failure indicator: Literature review. Journal of Global Economics, Management and Business Research, 8(1), 18-27.

Nam, J. H., \& Jinn, T. (2000). Bankruptcy prediction: Evidence from Korean listed companies during the IMF crisis. Journal of International Financial Management \& Accounting, 11(3), 178-197.

Newey, W. K., \& West, K. D. (1986). A simple, positive semi-definite, heteroscedasticity and autocorrelation consistent covariance matrix. Econometrica, 55, 703-709.

Nikkinen, J., \& Vähämaa, S. (2010). Terrorism and stock market sentiment. Financial Review, 45(2), 263-275.

Nikkinen, J., Omran, M. M., Sahlström, P., \& Äijö, J. (2008). Stock returns and volatility following the September 11 attacks: Evidence from 53 equity markets. International Review of Financial Analysis, 17(1), 27-46.

Pomerleano, M. (1999). The East Asia crisis and corporate finances: The untold micro story. The World Bank. Retrieved from https://elibrary.worldbank.org/doi/pdf/10.1596/1813-9450-1990.

Schipper, K., \& Thompson, R. (1983). The impact of merger-related regulations on the shareholders of acquiring firms. Journal of Accounting Research, 21(1), 184-221.

Thompson, R. (1985). Conditioning the return-generating process on firm-specific events: A discussion of event study methods. Journal of Financial and Quantitative Analysis, 20(2), 151-168. 